\title{
Grandparents Raising Grandchildren: Understanding Relationships ${ }^{1}$
}

Millie Ferrer-Chancy, Larry F. Forthun, Angela Falcone, and Joe Pergola ${ }^{2}$

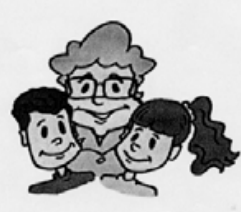

Goal: To help grandparents understand changes in relationships that may result from the decision to raise grandchildren

Sometimes life events do not happen the way we plan. You probably never expected that one day you would be raising your grandchildren. As you take on this new role, there will be many changes in the relationships you have with family and friends. Let's take a look at how your relationships may change from before and after you started raising your grandchild.

\section{Relationship with Family}

\section{Partner}

Before taking on this new responsibility, you probably spent a lot more time with your partner. Clearly, it will be hard to continue to build this relationship while spending less time together. Yet, if both

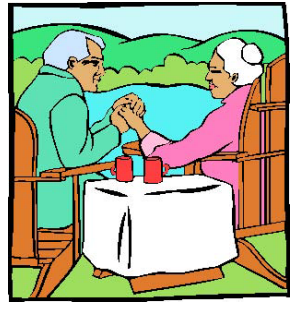
of you are committed to raising your grandchild, your positive influence will strengthen your family unit. Mutual support during this new challenge can also bring you closer together as a couple. Talk about your new role with each other and plan, in advance, how you will structure your time. Make sure you include spending time together without the grandchildren. As with any new parents, you will be challenged to find time to spend together. Make spending time together a priority.

\section{Adult Child}

As a result of parenting your grandchildren, you may experience changes in your relationship with your adult child, your grandchildren's parent. Whether your new role was planned or has resulted from a crisis, a change in your relationship is bound to happen. You may experience mixed feelings depending on your situation. Assuming responsibility for your grandchildren puts your adult child in the role of co-parent. Some adult children may accept this responsibility while others may not. Some may be invested in making lifestyle changes, while others may respond with anger or resentment.

If you are having difficulties in your relationship with your adult child, maintain open lines of communication. Avoid jumping to conclusions, using unkind words, or blaming (See: FCS 2191 Building Strong Families). Instead, be a good listener and try to see things from your child's point of view. Agree to disagree if you are unable to resolve conflict right away, yet return to the conversation in order to seek common ground. Although your primary responsibility is for the health and well-being of your grandchildren, be sure to separate your feelings about your adult child from your grandchildren's feelings about their parent.

Likewise, encourage visits between your grandchildren and their parents. But first, be sure the visits are consistent with any legal decisions about visitation. Then, make visits part of your grandchildren's routine. Plan visits in advance and be clear about your expectations for the visit.

Frequent unplanned visits can often disrupt your grandchildren's routine, leading to behavioral or emotional problems. Set limits that you are comfortable with and enforce them. Don't be afraid to say NO!

1. This document is FCS2190, one of a series of the Department of Family, Youth and Community Sciences, Florida Cooperative Extension Service, Institute of Food and Agricultural Sciences (IFAS), University of Florida. Publication date: December 2002. Revised: August 2009. Please visit the EDIS Web site at http://edis.ifas.ufl.edu.

2. Millie Ferrer-Chancy, Ph.D., interim dean, Florida Cooperative Extension Service, University of Florida; Larry F. Forthun, Ph.D., assistant professor, Department of Family, Youth and Community Sciences; Angela Falcone and Joe Pergola, former FYCS graduate students; Institute of Food and Agricultural Sciences, University of Florida, Gainesville, FL 32611. 
Finally, learn to let go. There are a variety of reasons why grandparents may find themselves raising their grandchildren. If you are raising your grandchildren because your adult child is not a fit parent, let go of any frustrations you may feel. Also, let go of any guilt you may feel about your own parenting. You may sometimes ask yourself what you did wrong as a parent that led to your adult child's behavior. Remember, your child is an adult and can make her or his own choices as well as experience the consequences of those choices. Their actions and choices are their responsibility; therefore, it is not your sole responsibility to fix things.

\section{Grandchild}

Before taking on the role of a caregiver, you may have had fewer responsibilities. Upon accepting this new role, you may be uncertain of how to parent your grandchild. Also, your grandchildren may not be

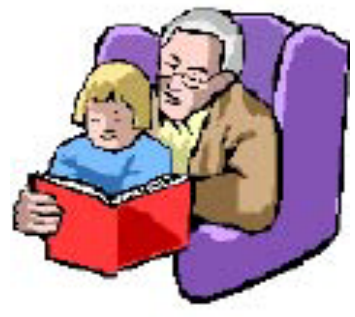
sure of what to expect from you. They may be leaving their home to live with you and will not only be separated from their parents, but also their friends, schoolmates, and other relationships within their community. This can be difficult for your grandchildren who may react negatively to the move. Likewise, they may be leaving a difficult home environment that may have persisted for many months or years.

To ease the transition, it is important for you and your partner to talk about these feelings with your grandchildren. By talking with your grandchildren, you may discover that you share many of the same feelings - for example, fear, sadness, or anxiety. You may also discover that you share many of the same expectations for what life will be like in your home. Discussing these expectations in advance can help to relieve some of the anxiety of moving into a new home and give everyone an opportunity to arrive at a common understanding of the rules, limits, and expectations of the household.

Likewise, make life a daily routine in your household. A consistent routine for meals, naps, bathing and bedtime will help your grandchildren adjust more easily to their new home. Help your grandchildren maintain their relationships with friends and provide opportunities for them to be engaged in activities that allow them to make new ones. Creating a sense of "normalcy" for the grandchildren in your home will help to make a difficult transition easier.

\section{Relationships with Friends}

With your new role as a parent, you may not have as much time to spend with your friends. Perhaps, as a result of your new role, you may also discover that you no longer share the same interests. Talk with your friends about your new responsibilities and let them know that you will continue to value their friendship even if you may not be able to see them as often.

On the other hand, you may find that you'll meet new friends that share the same challenges you are facing. You may meet these new friends through your grandchildren's school, at a grandparent support group, or at church. Finding and keeping friends who support and comfort you during these times is extremely important.

\section{Conclusion}

Becoming a parent for the second time can bring many changes to your relationships with family and friends. Many of these changes can be positive, like developing new relationships with your grandchildren, adult child, or friends. However, some changes may be challenging. Life's challenges provide us with an opportunity for growth. These times can bring out the best in us as we rise to meet these new challenges.

\section{Resources}

For a list of support groups in your area, visit the Florida Kinship Center at:

http://www.flkin.org/statewidegroups.asp

\section{References}

Bales, D. (2003). Helping grandchildren stay in contact with parents. The University of Georgia. http://www.fcs.uga.edu/ext/pubs/ecd.php?catego ry=Grandparents\%20Raising\%20Grandchildren

Callander, J. (1999). Second time around: Help for grandparents who raise their children's kids. Wilsonville, OR: BookPartners.

Poehlmann, J., et al. (2003). Children's contact with their parents. University of Wisconsin Extension. http://www.uwex.edu/relationships/

Hayslip, B., \& Kaminski, P.L. (2005). Grandparents raising their grandchildren. Marriage and Family Review, 37, 147-169. 